\title{
PENGARUH ORANG TUA TUNGGAL TERHADAP PEMBENTUKAN SIKAP ANAK DI DESA BONE-BONE KECAMATAN BARAKA KABUPATEN ENREKANG
}

\author{
Ahmad Sultra Rustan, Pahira, Muhammad Qadaruddin \\ Institut Agama Islam Negeri (IAIN) Parepare \\ Email:Pahira@gmail.com
}

\begin{abstract}
In every life someone will always be in touch with family. The family is a group that identifies themselves from its members consisting of two or more individuals, whether it is blood relations or legally, but functions in such a way that they consider themselves as family. It's different with single parent families, where there is only one parent, both father and mother. Family care patterns applied by parents in educating children are several ways: authoritarian parenting, muscle-loving parenting, democratic parenting, and caring patterns. The purpose of this study was to determine the influence of single parents on the formation of children's attitudes in Bone-Bone Village, Baraka District, Enrekang Regency. This research is a type of quantitative research that examines the relationship of two variables. The number of samples in this study amounted to 28 people using saturated sampling techniques. The data collection techniques used were questionnaires and documentation. The data analysis technique used is to create a helper table, simple regression analysis, find the Syx value, regression $b$ (Sb) and determine the value of the T test.

The results of this study indicate that (1) the care of single parents is in a pretty good category, namely: the average score of 36 which is located in the interval / qualification 39-35 is proven by analyzing the results of questionnaires from 28 respondents, the value of the range of variables $X$ divided by the number of classes variable X. (2) the formation of children's attitudes in Bone-Bone Village, Baraka District, Enrekang Regency is in a pretty good category, namely: an average score of 45 which is located in the 48-45 interval / qualification as evidenced by analyzing the questionnaire of 28 respondents namely the range value variable $Y$ is divided by the number of classes of variable $Y$. If the value of variable $X$ is higher then the value of variable $Y$ will also be higher. The dominant parenting pattern in this study is authoritative parenting, where care is high in demand and acceptance is also high. (3) Operant Conditioning and Social Learning Theory is very effective in forming children's attitudes. Where this theory is based on habituation and imitation of the environment. The results of the analysis on simple regression statistical tests, namely the $t$ test, obtained the hypothesis test results that that $t$ count ( $t 0)>$ from 15.33 t table is 2.05. (15,33> 2,05). Thus, H_odi reject and H_adi accept, thus it can be concluded that there is a single parent influence on the formation of children's attitudes in Bone-Bone Village, Baraka District, Enrekang Regency.
\end{abstract}

Keywords: Single Parents, Formation of Attitudes, Children. 


\section{PENDAHULUAN}

Berdasarkan wawancara dengan salah satu orang tua tunggal pada observasi awal mengatakan bahwa pangkal masalah yang sering dihadapi keluarga yang dipimpin oleh orang tua tunggal ialah masalah anak. Anak akan merasa sangat kehilangan salah satu orang yang sangat berarti dalam hidupnya. Anak yang ditinggal mati oleh salah satu orang tuanya berbeda dengan anak yang ditinggal cerai oleh orang tuanya.

Dengan melihat kondisi di lokasi penelitian, anak yang salah satu orangtuanya meninggal dunia kebanyakan menjadi lebih kuat dan lebih mandiri. Sedangkan anak yang mempunyai orang tua yang bercerai tumbuh menjadi anak yang agresif, pemarah, nakal, lebih sering ikut-ikutan dengan teman-temanya melakukan hal-hal yang menurutnya dapat membuatnya bahagia seperti merokok dll. Sehingga sikap anak yang ada di lokasi jauh berbeda dengan sikap anak yang mempunyai orang tua utuh. Jadi pengasuhan yang diterapkan oleh orang tua tunggal sangat berpengaruh dalam pembentukan sikap anak yang baik. Adapun anak yang menjadi fokus dalam penelitian ini adalah anak yang berumur 6 sampai 12 tahun dimana anak pada masa ini masih sangat membutuhkan pengasuhan dari orang tuanya karena mereka masih sangat bergantung kepada orang tua dalam segala hal.

Dengan demikian, orang tua tunggal baik ayah maupun ibu harus memiliki usaha yang ekstra dalam mendidik, mengasuh dan memelihara anak-anaknya, terutama pada masa sekarang. Orang tua harus mampu mengasuh anaknya dengan baik jika menginginkan anak yang bisa menempatkan diri pada zamannya karena pengasuhan orang tua terhadap anaknya merupakan hal yang paling penting dalam pembentukan sikap anak. Sebagaimana firman Allah dalam surah At-Tahrim ayat 6:

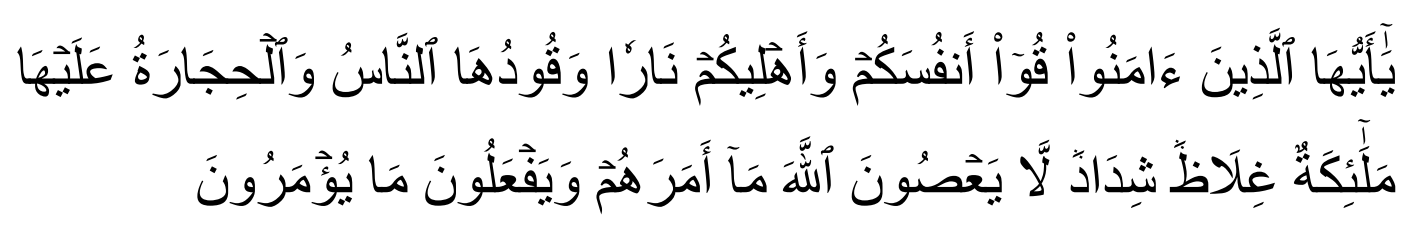


Terjemahannya :

Hai orang-orang yang beriman, peliharalah dirimu dan keluargamu dari api neraka yang bahan bakarnya adalah manusia dan batu; penjaganya malaikat-malaikat yang kasar, keras, dan tidak mendurhakai Allah terhadap apa yang diperintahkan-Nya kepada mereka dan selalu mengerjakan apa yang diperintahkan.

Jadi dari ayat ini jelas bahwa sikap dan perilaku orang tua sangat berpengaruh pada perkembangan anak karena anak sangat cepat meniru hal-hal yang terjadi di lingkungan sekitarnya tanpa dapat membedakan apakah itu hal baik atau buruk. Sama halnya ketika anak dididik dengan kekerasan maka anak itu akan tumbuh menjadi orang yang suka berbuat kasar, tidak mampu mengontrol emosi kehilangan kreativitas dan suka berbohong.

Berdasarkan uraian di atas maka penulis tertarik untuk meneliti tentang pengaruh orang tua tunggal terhadap pembentukan sikap anak. Penulis akan meneliti bagaimana sikap anak yang berumur 6 sampai 12 tahun yang diasuh oleh orang tua tunggal. Dalam penelitian ini lebih difokuskan pada bagiamana pola asuh orang tua tunggal dalam pembentukan sikap anak.

\section{PEMBAHASAN}

\section{Orang Tua Tunggal (Single Parent)}

Orang tua tunggal atau Single parent adalah orang tua satu-satunya. Orangtua satu-satunya dalam konteks ini adalah keluarga dari orang tua tunggal sehingga dalam mengasuh dan membesarkan anak-anaknya sendiri tidak dengan bantuan pasangannya, karena istri atau suami mereka meninggal dunia atau sudah berpisah/cerai. Jadi keluarga single parent adalah hubungan perkawinan, karena ada beberapa sebab tertentu menjadikan orang tua tunggal. Dalam penelitian ini difokuskan pada orang tua tunggal (single parent) karena telah ditinggal meninggal dunia maupun cerai oleh pasangannya.

Orang tua tunggal bisa dikarenakan perceraian atau salah satu ada yang meninggal, sehingga memaksa suami atau istri untuk bertugas sendiri dalam mendidik anak, dalam keluarga single parent memiliki serangkaian masalah yang tidak sama dengan keluarga yang utuh. Hal itu kita kembalikan pada fungsi 
keluarga yaitu memaksimalkan peran orang tua dalam pembentukan sikap, kepribadian, potensi, dan moral pada anak. Karena sesungguhnya anak dilahirkan dalam keadaan fitrah dan membawa potensi masing-masing, tugas orang tua adalah memberikan kebaikan pada anak sehingga anak juga akan terbentuk menjadi baik.

\section{Faktor Penyebab Menjadi Orang Tua Tunggal (Single Parent)}

Orang tua tunggal tidak terjadi begitu saja, melainkan karena beberapa sebab yang menjadikan orang tua tunggal tersebut harus mendidik anak tanpa bantuan pasangannya. Penyebab terjadinya orang tua tunggal dalam penelitian ini hanya dibagi dalam dua sebab, yaitu : perceraian dan meninggal dunia.

\section{Perceraian}

Menurut kamus besar bahasa Indonesia perceraian sendiri memiliki arti perpisahan atau putusnya hubungan sebagai suami istri dan keluarga memiliki arti hubungan darah karena ikatan pernikahan. Sehingga perceraian keluarga dapat diartikan bahwa berpisahnya hubungan suami istri yang melalui ikatan pernikahan. $^{1}$

Jika dilihat dari sudut hukum islam perceraian merupakan perbuatan yang halal yang paling dibenci olehAllah SWT, seperti dalam hadist riwayat Abu Daud, Ibnu Majah, dan Al-hakim dari Ibnu Umar yang mempunyai arti "Perbuatan halal yang dibenci oleh Allah adalah perceraian”.

Hal ini disebabkan karena perceraian sangat bertentangan dengan tujuan perkawinan yaitu membentuk keluarga yang sakinah mawaddah warahmah. Perceraian juga mempunyai dampak bagi suami maupun istri. Akan tetapi yang paling banyak dampaknya ialah terhadap anak akibat perceraian orang tua.

Al-Qur'an menggambarkan beberapa situasi dalam kehidupan suami istri yang menunjukkan adanya keretakan dalam rumah tangga yang berujung perceraian. Keretakan dan kemelut rumah tangga itu bermula dari tidak 2008) h. 261

${ }^{1}$ Dendy Sugono, Kamus Besar Bahasa Indonesia, (Jakarta: PT Gramedia Pustaka Utama 
berjalannya aturan yang ditetapkan Allah bagi kehidupan suami istri dalam bentuk hak dan kewajiban yang seharusnya dipenuhi oleh kedua belah pihak. Allah menjelaskan beberapa usaha yang harus dilakukan dalam menghadapi kemelut rumah tangga sehingga tidak terjadi perceraian. Dampak perceraian yang sangat banyak maka perceraian hanya boleh dilakukan ketika keadaan sudah terpaksa atau karena kemelut rumah tangga yang sudah sangat gawat, beberapa cara yang digunakan untuk menyelesaikan masalah dalam keluarga tersebut tidak berhasil diselesaikan.

\section{Meninggal Dunia}

Ketika orang tua meninggal dunia, tidak ada lagi hal yang sama. Earl Grollman menulis, "Dunia tidak akan lagi menjadi tempat yang senyaaman sebelumnya. Rancangan familier dalam kehidupan keluarga benar-benar rusak". 2 Meski ada perbedaan cara anak dan orang tua menunjukkan kedukaan, ada pula banyak kesamaan.

Bagi anak, kematian orangtua merupakan "kehilangan terburuk"anak telah kehilangan sosok tempat ia bergantung untuk mendapatkan keamanan dalam hidup, dan orang tua kehilangan pendamping hidupnya. John Bowlby menjelaskan empat fase dalam proses kedukaan. Pada kondisi anak yang ditinggal mati oleh salah satu orang tuanya berbeda dengan kasus perceraian.

1. Sebuah periode kekakuan yang berlangsung berjam-jam atau bermingguminggu dimana seseorang harus menerima fakta kematian, tetapi belum mampu meredakan emosi karena lukanya sangat besar.

2. Periode memprotes dan merindukan di mana seseorang menolak menerima fakta kematian dan mencari-cari orangtua.

3. Periode kesedihan dan putus asa di mana kenyataan kematian telah diterima secara emosional dan hidup tanpa orang tersebut terlihat tidak tertahankan

4. Periode pengaturan hidup kembali untuk meneruskan hidup tanpa orang tersebut.

\footnotetext{
${ }^{2}$ Jane Brooks, The Process Of Parenting (Yogyakarta: Pustaka pelajar 2011) h, 788
} 


\section{Pengaruh Pengasuhan Orang Tua Tunggal Terhadap Pembentukan Sikap} Anak

Pengasuhan anak dipercaya memiliki dampak terhadap perkembangan individu. Dalam memahami dampak pengasuhan orang tua terhadap perkembangan anak pada mulanya terdapat dua aliran yang dominan, yaitu psikoanalitik dan belajar sosial ( social learning). Pada perkembangan yang lebih kontemporer kajian pengasuhan anak terpolarisasi dalam dua pendekatan, yaitu pendekatan tipologi atau gaya pengasuhan (parenting style) dan pendekatan interaksi sosial (social interaction) atau parent child system. Pendekatan tipologi memahami bahwa teerdapat 2 dimensi dalam pelaksanaan tugas pengasuhan, yaitu demandigness dan responsiveness. Demandigness merupakan dimensi yang berkaitan dengan tuntutan-tuntutan orang tua mengenai keinginan menjadikan anak sebagai bagian dari keluarga, harapan tentang perilaku dewasa, disiplin, penyediaan survisi, dan upaya menghadapi masalah perilaku. Faktor ini terwujud dalam tindakan kontrol dan regulasi yang dilakukan oleh orang tua. Responsiveness merupakan dimensi yang berkaitan dengan tanggapan orang tua dalam hal membimbing kepribadian anak, membentuk ketegasan sikap, pengaturan diri, dan pemenuhan kebutuhan-kebutuhan khusus. Faktor ini terwujud dalam tindakan penerimaan, suportif, sensitif terhadap kebutuhan, pemberian afeksi dan penghargaan.

Pendekatan tipologi dipelopori oleh Baumrind yang mengajukan empat gaya pengasuhan sebagai kombinasi dari dua faktor tersebut, yaitu authoritative, authoritarian, permissive, dan rejecting-neglecting. 
Matriks kombinasi dua dimensi dalam pengasuhan dapat dilihat sebagai berikut.

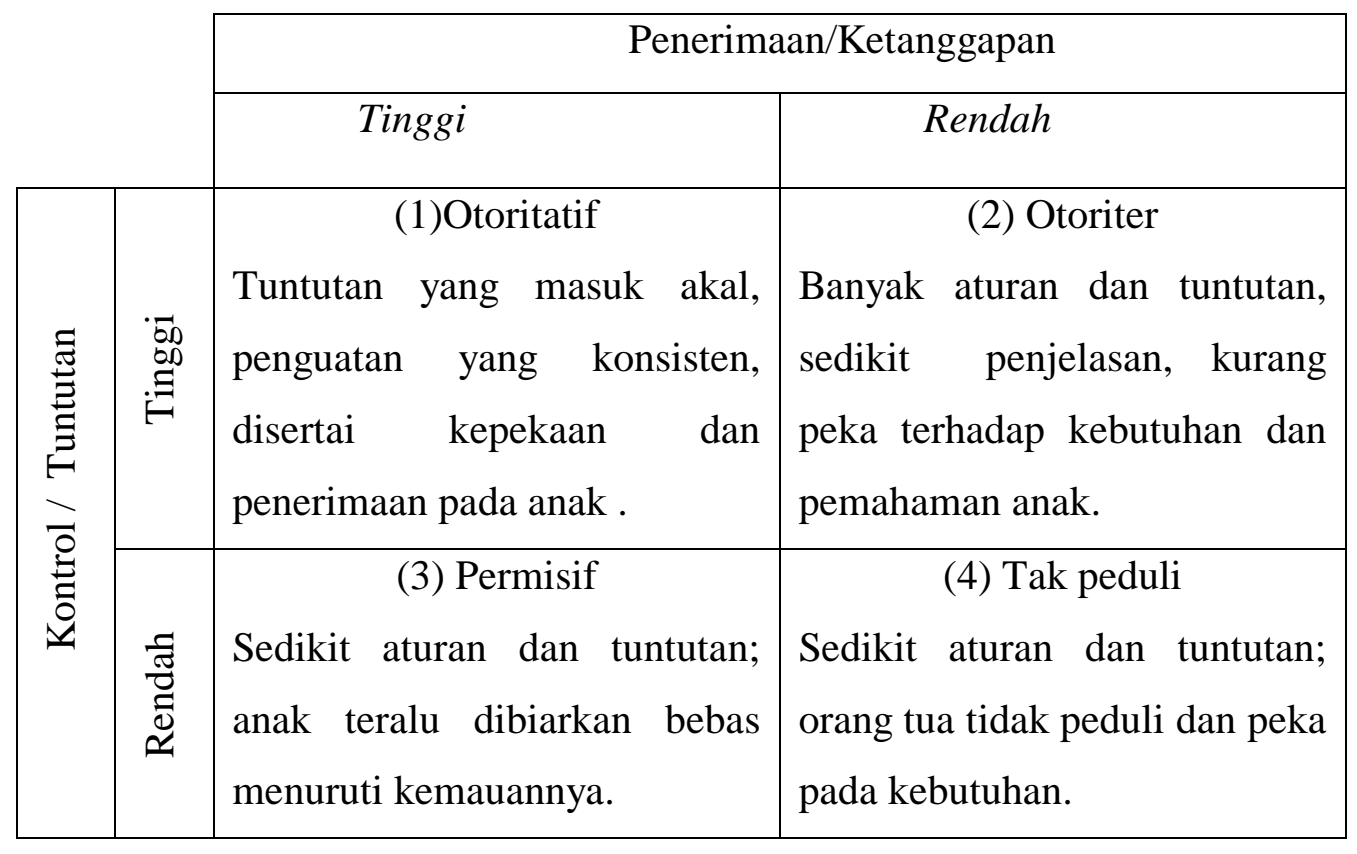

Gambar : Matriks Kombinasi Dua Dimensi dalam Pengasuhan Sumber : Shaffer (2002)

Gaya pengasuhan merupakan serangkaian sikap yang ditunjukkan oleh orang tua kepada anak untuk menciptakan iklim emosi yang melingkupi interaksi orang tua- anak. ${ }^{3}$ Gaya pengasuhan berbeda dengan perilaku pengasuhan yang bercirikan oleh tindakan spesifik dan tujuan tertentu dari sosialisasi. Gaya pengasuhan otoritatif dianggap sebagai gaya pengasuhan yang paling efektif menghasilakn akibat-akibat positif pada anak.

\section{Defenisi Sikap}

Sikap (attitude) adalah istilah yang mencerminkan rasa senang, tidak senang atau perasaan biasa-biasa saja (netral) dari seseorang terhadap sesuatu. "sesuatu" itu bisa benda, kejadian, situasi, orang-oran g atau kelompok. Kalau yang timbul terhadap sesuatu itu adalah perasaan senang, maka disebut sikap

\footnotetext{
${ }^{3}$ Sri Lestari, Psikologi Keluarga (Kencana Prenamedia Group), h.49
} 
positif, sedangkan kalau perasaan tak senang, maka disebut sikap negatif. Kalau tidak timbul perasaan apa-apa, berarti sikapnya netral. ${ }^{4}$

Sikap dinyatakan dalam tiga dominaan ABC, yaitu Affect, Behaviour, dan cognition. Affect adalah perasaan yang timbul (senang, tak senang), behavior adalah perilaku yang mengikuti perasaan itu (mendekat, menghindar), dan cognition adalah penilaian terhadap objek sikap (bagus tidak bagus). ${ }^{5}$

Chaplin menegaskan bahwa sumber dari sikap bersifat kultural, familiar, dan personal. Artinya, kita cenderung beranggapan bahwa sikap-sikap itu akan berlaku dalam suatu kebudayaan tertentu, selaku tempat individu dibesarkan. Jadi, ada semacam sikap kolektif (collective attitude) yang menjadi sterotipe sikap kelompok budaya masyarakat tertentu. Sebagian besar dari sikap itu berlangsung dari generasi ke generasi di dalam struktur keluarga. Akan tetapi, beberapa dari tingkah laku individu juga berkembang selaku orang dewasa berdasarkan pengalaman individu itu sendiri. Para ahli psikologi sosial bahkan percaya, bahwa sumber-sumber penting dari sikap individu adalah propaganda dan sugesti dari penguasa, pengusaha, lembaga pendidikan, dan lembaga-lembaga lainnya yang secara sengaja diprogramkan untuk memengaruhi sikap dan perilaku. Dalam konteks sikap ini, menurut Stephen R. Covey, ada tiga teori determinisme yang diterima secara luas, baik sendiri-sendiri maupun kombinasi untuk menjelaskan sikap manusia, yaitu :

1. Determinisme Genetis (genetic determinism) berpandangan bahwa sikap individu diturunkan oleh sikap kakek - neneknya. Itulah sebabnya, seseorang memiliki sikap dan tabiat sebagaimana sikap dan tabiat nenek moyangnya. Sikap kakek - nenek diturunkan ke dalam DNA. Oleh karena itu, jika kakek - neneknya seorang yang mudah marah, seseorang akan memiliki sikap mudah marah juga.

2. Determinisme psikis (psychic determinism) berpandangan bahwa sikap individu merupakan hasil dari perlakuan, pola asuh, atau pendidikan

\footnotetext{
${ }^{4}$ Sarlito W.Sarwono, Pengantar Psikologi Umum, (Jakarta; Rajawali Pers 2014)h.
} 
orang tua yang diberikan kepada anaknya. Pengasuhan yang diterima individu berupa pengalaman masa kanak-kanak pada dasarnya membentuk kecenderungan pribadi dan karakter individu, termasuk dalam pembentukan sikap individu. Jika seseorang grogi, takut, atau bahkan stress jika harus berdiri dan berbicara di depan banyak orang, itu merupakan hasil dari cara orang tua mendidik, memperlakukan, atau mengasuhnya.

3. Determinisme lingkungan (environmental determinism) berpandangan bahwa perkembangan sikap seseorang sangat dipengaruhi oleh lingkungan tempat individu tinggal dan bagaimana lingkungan memperlakukan individu tersebut. Bagaimana atasan/pimpinan memperlakukan kita, bagimana pasangan memperlakukan kita, bagaimana pasangan kita memperlakukan kita, situasi ekonomi, atau kebijakan-kebijakan pemerintah, semuanya membentuk perkembangan sikap individu.

Sikap merupakan salah satu aspek psikologis individu yang sangat penting karena sikap merupakan kecenderungan untuk berperilaku sehingga akan banyak mewarnai perilaku seseorang. Sikap setiap orang berbeda atau bervariasi, baik kualitas maupun jenisnya sehingga perilaku individu menjadi bervariasi. Pentingnya aspek sikap dalam kehidupan individu, mendorong para psikolog untuk mengembangkan teknik dan instrumen untuk mengukur sikap manusia. Beberapa tipe skala sikap telah dikembangkan untuk mengukur sikap individu, kelompok, maupun massa untuk mengukur pendapat umum sebagai dasar penaksiran dan penilaian sikap. 


\section{Fungsi Sikap}

Katz mengidentifikasi fungsi sikap utama sebagai berikut : ${ }^{6}$

1. Fungsi instrumental, penyelarasan atau kebermanfaatan. Sejumlah sikap dipegang kuat karena manusia berjuang keras untuk memaksimalkan penghargaan dalam lingkungan eksternal mereka dan meminimalkan sanksi.

2. Fungsi pertahanan diri. Sejumlah sikap kuat dipegang karena manusia melindungi ego mereka dari hasrat mereka sendiri yang tidak dapat diterima atau dari pengetahuan tentang kekuatan-kekuatan yang mengancam dari luar. Perasaan rendah diri sering diproyeksikan pada anggota-anggota sebuah kelompok minoritas sebagai alat memperkuat ego.

3. Fungsi ekspresi nilai. Beberapa sikap dipegang kuat karena memungkinkan seseorang memberikan ekspresi positif pada nilai-nilai sentral dan pada jati diri.

4. Fungsi pengetahuan. Beberapa sikap dipegang kuat karena memuaskan kebutuhan akan pengetahuan atau memberikan struktur dan makna pada sesuatu yang jika tanpanya dunia akan kacau. Banyak keyakinan reigius memiliki fungsi ini, juga sikap-sikap lain seperti norma-norma budaya yang berlaku.

5.

\section{Struktur Sikap}

Mengikuti skema triadik, struktur sikap terdiri atas tiga komponen yang saling menunjuang yaitu komponen kognitif (cognitive) komponen afektif, (affective) komponen konatif (conative).

\section{Komponen Kognitif}

Komponen kognitif berisi kepercayaan seseorang mengenai apa yang berlaku atau apa yang benar bagi objek sikap. Mengapa orang percaya atau mempunyai kepercayaan? Kepercayaan datang dari apa yang telah kita lihat atau apa yang telah kita ketahui. Berdasarkan apa yang telah kita lihat itu kemudian

${ }^{6}$ Werner J. Severin, Teori komunikasi, Sejarah, Metode, Dan Terapan Di Dalam Media Massa Cet.k V (Kencana ; prenadamedia group 2011 )h.197 
terbentuk suatu ide atau gagasan mengenai sifat atau karakteristik umum suatu objek.

\section{Komponen Afektif}

Komponen afektif menyangkut masalah emosional subjektif seseorang terhadap suatu objek sikap. secara umum, komponen ini disamakan dengan perasaan yang dimiliki terhadap sesuatu.

\section{Komponen Perilaku}

Komponen perilaku atau konatif dalam struktur sikap menunjukkan bagaimana perilaku atau kecenderungan berperilaku yang ada dalam diri seseorang berkaitan dengan objek sikap yang dihadapinya. Kaitan ini didasari oleh asumsi bahwa kepercayaan dan perasaan banyak mempengaruhi perilaku. Maksudnya bagaimana orang berperilaku dalam situasi tertentu dan terhadap stimulus tertentu akan banyak ditentukan oleh bagaimana kepercayaan dan perasaannya terhadap stimulus tersebut. Kecenderungan berperilaku secara konsisten, selaras dengan kepercayaan dan perasaan ini membentuk sikap individual.

Konsistensi antara kepercayaan sebagai komponen kognitif, perasaan sabagai komponen afektif, dan tendensi perilaku sebagai komponen konatif seperti itulah yang menjadi landasan dalam usaha menyimpulkan sikap yang dicerminkan oleh jawaban terhadap skala sikap.

\section{Pembentukan Sikap}

Dalam interaksi sosialnya, individu bereaksi membentuk pola sikap tertentu terhadap berbagai objek psikologis yang dihadapinya. Diantara berbagai faktor yang mempengaruhi pembentukan sikap adalah pengalaman pribadi, kebudayaan, orang lain yang dianggap penting, media masaa, institusi atau lembaga pendidikan dan lembaga agama, serta faktor emosi dalam diri individu.

\section{Pengalaman Pribadi}

Apa yang telah dan sedang kita alami akan ikut membentuk dan memengaruhi penghayatan kita terhadap stimulus sosial. Tanggapan akan menjadi 
salah satu dasar terbentuknya sikap. Pembentukan kesan atau tanggapan terhadap objek merupakan proses kompleks dalam diri individu yang melibatkan individu yang bersangkutan, situasi dimana tanggapan itu terbentuk, dan atribut atau ciriciri objektif yang dimiliki oleh stimulus.

\section{Pengaruh Orang Lain Yang Dianggap Penting}

Orang lain disekitar kita merupakan salah satu diantara komponen sosial yang ikut mempengaruhi sikap kita. Pada umumnya, individu cenderung untuk memiliki sikap yang konformis atau searah dengan sikap orang yang dianggapnya penting. Kecenderungan ini antara lain dimotivasi oleh keinginan untuk berafiliasi dan keinginan untuk menghindari konflik dengan orang yang dianggap penting tersebut.

\section{Pengaruh Kebudayaan}

Seorang ahli Psikologi yang terkenal, Burrhus Frederic Skinner sangat menekankan pengaruh lingkungan (termasuk kebudayaan) dalam membentuk pribadi seseorang. Kepribadian, katanya, tidak lain daripada pola perilaku yang konsisten yang menggambarkan sejarah reinforcement yang kita alami (Hergenhahn, 1982). Kita memiliki pola sikap dan perilaku tertentu dikarenakan kita mendapat reinforcement (penguatan, ganjaran) dari mayarakat untuk sikap dan perilaku tersebut, bukan untuk sikap dan perilaku yang lain.

Tanpa kita sadari, kebudayaan telah menanamkan garis pengarah sikap kita terhadap berbagai masalah. Kebudayaan telah mewarnai sikap anggota masyarakatnya, karena kebudayaan pulalah yang memberi corak pengalamanpengalaman yang menjadi anggota kelompok masyarakat asuhannya. Hanya kepribadian individu yang telah mapan dan kuatlah yang dapat memudarkan dominasi kebudayaan dalam pembentukan sikap individual.

\section{Media Massa}

Sebagai sarana komunikasi, berbagai bentuk media massa seperti televisi, radio, suratkabar, majalah, dll. Mempunyai pengaruh besar dalam pembentukan opini dan kepercayaan orang. Dalam penyampaian informasi sebagai tugas 
pokonya, media massa membawa pula pesan-pesan yang berisi sugesti yang mengarahkan opini seseorang.

Walaupun pengaruh media massa tidaklah sebesar pengaruh interaksi individu secara langsung, namun dalam proses pembentukan dan perubahan sikap, peranan media massa tidak kecil artinya.

\section{Lembaga Pendidikan dan Lembaga Agama}

Lembaga pendidikan serta lembaga sebagai suatu system mempunyai pengaruh dalam pembentukan sikap dikarenakan keduanya meletakkan dasar pengertian dan konsep moral dalam diri individu. Pemahaman akan baik dan buruk, garis pemisah antara sesuatu yang boleh dan yang tidak boleh dilakukan diperoleh dari pendidikan dan dari pusat keagamaan serta ajaran-ajarannya. Dikarenakan konsep moral dan ajaran agama sangat menentukan system kepercayaan maka tidaklah mengeherankan kalau pada gilirannya kemudian konsep tersebut ikut berperanan dalam menentukan sikap individu terhadap sesuatu hal.

\section{Pengaruh Faktor Emosional}

Tidak semua bentuk sikap ditentukan oleh situasi lingkungan dan pengalaman pribadi seseorang. Kadang-kadang, suatu bentuk sikap merupakan pernyataan yang didasari oleh emosi yang berfungsi sebagai semacam penyaluran frustasi atau pengalihan bentuk mekanisme ego. Sikap demikian dapat merupakan sikap yang sementara dan segera berlalu begitu frustasi telah hilang akan tetapi dapat pula merupakan sikap yang lebih persisten dan bertahan lama.

\section{Pengasuhan Orang Tua Tunggal}

Pola asuh orang tua yaitu pola pengasuhan orang tua terhadap anak,yaitu bagaimana orangtua memperlakukan anak, mendidik, membimbing, mendisiplinkan anak, membentuk sikap anak serta melindungi anak dalam mencapai proses kedewasaan sampai dengan membentuk perilaku anak sesuai dengan norma dan nilai yang baik sesuai dengan kehidupan masyarakat. Pola asuh orang tua sangat berperan dalam perkembangan, kualitas pendidikan serta kepribadian anak. Oleh karena itu pola asuh yang diterapkan oleh orang tua perlu 
mendapat perhatian. Ada 4 macam pola asuh yang digunakan orang tua dalam membentuk sikap anak yaitu pola asuh otoritatif, pola asuh otoriter, pola asuh permisif, pola asuh tidak peduli. Dimana pola asuh otoritatif yaitu pola pengasuhan orang tua yang tinggi tuntutan (demandigness) dan tanggapan (responsiveness). Ciri dari pengasuhan ini bersikap hangat namun tegas, mengatur standar agar dapat melaksanakannya dan memberi harapan yang konsisten terhadap kebutuhan dan kemampuan anak, memberi kesempatan anak untuk berkembang otonomi dan mampu mengarahkan diri, namun anak harus bertanggung jawab terhadap tingkah lakunya. Pola asuh otoriter yaitu pengasuhan orang tua yang tinggi tuntutan namun rendah tanggapan. Ciri dari pengasuhan ini memberi nilai tinggi pada kepatuhan dan dipenuhi permintaannya, cenderung lebih suka menghukum, bersifat absolut dan penuh disiplin, orang tua meminta anaknya menerima segala sesuatu tanpa pertanyaan. Pola asuh permisif yaitu pola pengasuhan dengan orang tua yang rendah pada tuntutan namun tinggi pada tanggapan. Ciri sangat menerima anaknya dan lebih pasif dalam persoalan disiplin, sangat sedikit menuntut anak-anaknya. Memberi kebebasan kepada anaknya untuk bertindak tanpa batasan dan lebih senang menganggap diri mereka sebagai pusat bagi anak-anaknya, tanpa peduli anaknya menganggap anaknya atau tidak. Pola asuh tidak peduli yaitu pola yang rendah tanggapan dan rendah pula tuntutan. Ciri dari pengasuhan tidak peduli sama halnya dengan pengasuhan acuh tak acuh yaitu sangat sedikit waktu dan energi saat harus berinteraksi dengan anak, melakukan sesuatu dengan anaknya hanya secukupnya saja, sangat sedikit mengerti aktivitas dan keberadaan anak.

Pada penelitian ini dengan jumlah populasi sebanyak 28 responden menunjukkan bahwa pola asuh yang paling ideal yang diterapkan oleh orang tua tunggal dalam pembentukan sikap anak yaitu pola asuh otoritatif. Hasil penelitian membuktikan bahwa pola asuh orang tua tunggal dalam penelitian ini khususnya pola asuh otoritatif memberikan kontribusi positif dan signifikan terhadap pembentukan sikap anak di Desa Bone-Bone Kecamatan Baraka Kabupaten Enrekang. Besarnya koefisien regresi pada pola asuh orang tua tunggal dengan 
pembentukan sikap anak yaitu 0.030. Meskipun nilai koefisien regresi pola asuh orang tua tunggal dan pembentukan sikap anak rendah, tetapi hal ini menunjukkan bahwa adanya pengaruh orang tua tunggal terhadap pembentukan sikap anak di Desa Bone-Bone Kecamatan Baraka Kabupaten Enrekang. Kemudian dari penelitian ini diperoleh hasil nilai interval pada pengasuhan oang tua tunggal (4,5 dibulatkan $\rightarrow 5$ ) bahwa nilai mean (rata-rata) dari variabel $\mathrm{X}$ tentang orang tua tunggal adalah 36 terletak pada interval 39-35 dimana hasil ini tergolong cukup baik.

\section{Pembentukan Sikap}

Sikap yaitu perasaan suka atau tidak suka terhadap sesuatu sehingga hal itu menimbulkan perilaku atau tingkah laku seorang anak terhadap apa yang di alaminya. Sikap anak bisa saja terbentuk dari lingkungannya, dari pengalaman pribadi dan hasil dari pengasuhan orang tua dalam kehidupan sehari-harinya. Tetapi yang paling berperan dalam pembentukan sikap anak sejak dini adalah lingkungan keluarga terutama orang tua. Dengan pengasuhan yang diterapkan oleh orang tualah yang dapat membentuk sikap anak secara permanen. Seorang anak dapat berperilaku sebagaimana yang diajarkan, dicontohkan oleh orang tuanya. Karena seorang anak akan terus menerus melakukan hal-hal yang dilihat, diamati dalam kesehariaanya. Seperti pada teori operant conditioning bahwa proses pembiasaan yang akan mengubah tingkah laku individu yang sering mengontrol seseorang untuk berperilaku, baik itu di rumah, di sekolah, maupun di lingkungan sekitar. Dalam teori operant conditioning ini terdapat dua penguatan (reinforcement). Yaitu adanya penguatan positif dan penguatan negatif. Dimana penguatan positif yaitu suatu rangsangan (stimulus) yang memperkuat atau mendorong suatu respon (tingkah laku tertentu). Penguatan ini berbentuk reward (ganjaran, hadiah atau imbalan) baik secara verbal (kata-kata atau ucapan pujian) maupun secara non-verbal (isyarat, senyuman). Contoh pujian (sebagai rangsangan) anak berhasil melaksanakan tanggung jawab yang telah diberikan oleh orang tuanya, akan memperkuat, memperteguh, atau mendorong anak untuk 
lebih bersungguh-sungguh dalam melaksanakan tanggung jawab yang diberikan. Sedangkan penguatan negatif yaitu suatu rangsangan (stimulus) yang mendorong seseorang untuk menghindari respon tertentu yang konsekuensi atau dampaknya tidak memuaskan (menyakitkan atau tidak menyenangkan). Dalam teori sosial learning sikap dapat terbentuk dari hasil belajar melalui pengamatan secara selektif dan mengingat tigkah laku orang lain. Sama halnya dengan pengasuhan orang tua tunggal karena setiap apa yang diajarkan dan dicontohkan oleh orang tua, seorang anak akan belajar dari setiap pengasuhan yang diterapkan oleh orang tua. inti dari sosial learning adalah pemodelan (tiruan) meruapakan salah satu langkah paling penting dalam pembelajaran, proses pembentukan sikap pada individu.

Pada penelitian ini dengan jumlah responden sebanyak 28 orang hasil analisisnya, pembentukan sikap itu berawal dari pembiasaan individu dan hasil tiruan atau belajar dari orang lain. Dengan hasil nilai interval pada pembentukan sikap anak (3,6 dibulatkan $\rightarrow 4$ ) dengan nilai rata-rata (mean) terletak pada interval 48-45 dengan hasil tergolong cukap baik.

Penelitian ini di laksanakan di Desa Bone-Bone Kecamatan Baraka Kabupaten Enrekang dengan jumlah populasi sebanyak 28 orang kemudian semua jumlah populasi dijadikan sampel karena peneliti menggunakan sampling jenuh dimana sampling jenuh ini semua jumlah populasi dijadikan sampel karena kurang dari 30 populasi.

Teknik dan instrument pengumpulan data pada penelitian ini menggunakan angket atau kuesioner dan dokumentasi. Sebelum melakukan teknik analisis data, maka terlebih dahulu peneliti melakukan pengujian persyaratan analisis data yaitu, membuat tabel penolong, analisis regresi sederhana, mencari nilai Syx, regresi b (Sb) dan menentukan nilai uji $\mathrm{T}$.

Adapun hasil analisis pada pegujian statistik inferensial yaitu uji $t$, diperoleh hasil uji hipotesis $\mathrm{t}_{\text {hitung }}=>15,33$ dari $\mathrm{t}_{\text {tabel }}=2,05$. Jadi, $H_{a}$ di terima dan $H_{o}$ di tolak. Dengan demikian dapat disimpulkan bahwa, dengan menggunakan rumus regresi sederhana, artinya bahwa ada pengaruh orang tua tunggal terhadap 
pembentukan sikap anak di Desa Bone-Bone Kecamatan Baraka Kabupaten Enrekang.

Dari penjabaran tersebut maka pengasuhan orang tua tunggal dan proses pembiasaan, tiruan dan hasil belajar dari orang lain salah satu faktor yang mempengaruhi pembentukan sikap anak. Meskipun nilai pengaruh pola asuh terhadap pembentukan sikap anak tergolong cukup baik, tetapi orangtua tunggal perlu mencermati cara yang digunakan untuk mendidik dan mengasuh anaknya agar pembentukan sikap anak sejak dini terbentuk dengan baik sesuai yang diharapkan setiap orang.

\section{PENUTUP}

\section{Kesimpulan}

Pengasuhan orang tua tunggal berada pada kategori cukup baik, dengan menganalisis angket yang dibagikan kepada 28 responden, mengenai pola asuh orang tua yang diterapkan oleh orang tua tunggal ternyata pola asuh otoritatif yang lebih dominan digunakan dalam membentuk sikap anak. Kemudian pembentukan sikap anak di Desa Bone-Bone berada pada kategori cukup baik, dengan menganalisis angket yang dibagikan kepada 28 responden, menunjukkan bahwa pembentukan sikap anak masih perlu ditingkatkan agar lebih baik dalam pembentukan sikap. Meskipun sebagian sikap anak berada dikategori sedang.

Terdapat pengaruh antara pengasuhan orang tua tunggal terhadap pembentukan sikap anak di Desa Bone-Bone Kecamatan Baraka Kabupaten Enrekang. Dimana pengasuhan yang dominan yang digunakan oleh orang tua tunggal dalam pembentukan sikap anak yaitu pola asuh otoritatif. Pola asuh ini mempunyai ciri yaitu tinggi tuntutan dan tanggapan terhadap kebutuhan dan pemahaman anak. Dengan menerapkan teori operant conditioning dan social learning dalam pembentukan sikap anak sangat efektif karena berdasarkan pada pembiasaan dan peniruan anak terhadap lingkungannya. Berdasarkan hasil uji dengan menggunakan rumus analisis regresi sederhana bahwa $t_{\text {hitung }}>t_{\text {tabel. }}$ Jadi $h_{a}$ diterima dan $h_{o}$ ditolak. Dengan hasil uji hipotesis $t_{\text {hitung }}=15,33>$ dari $t_{\text {tabel }}=2,05$ 


\section{DAFTAR PUSTAKA}

Bungin, Burhan2007. Sosiologi Komunikasi: Teori, Paradigma, dan Diskursus Teknologi di Masyarakat, Cet 2; Jakarta: Kencana Prenada Media Group.

Basrowi dan Suwandi, 2008. Memahami Penelitian Kualitatif, Cet. I, Jakarta: PT Renika Cipta.

Devito, Joseph A, 1997. Komunikasi Antarmanusia. Cet. V; Jakarta: Profesional Books.

Denzin, Norman K \& Yvonna S. Lincoln (eds), 2009. Handbook of Qualitative Research, terj. Dariyanto, badru samsu fata dan Jhon Rinald, Handbook of Qualitative Research (Yogyakrta: Pusaka Pelajar).

Effendy, Onong Uchjana, Ilmu Komunikasi Teori Dan Praktek

Feldman S Robert, 2012, Pengantar Psikologi (Edisi 10 buku 2, Jakarta: Salemba Humanika)

Moleong, Lexy J. 1998. Metodeologi Penelitian Kualitatif, Cet. IV, Jakarta: PT Rineka Cipta.

Mulyana, Deddy, 2008. Metode Penelitian Kualitatif, Paradigma baru ilmu penelitian komunikasi dan ilmu sosial lainnya, Cet. V; Bandung: Remaja Rosdakarya.

Rahmat Jalaluddin, 2007 Psikologi Komunikasi, Bandung: PT Remaja Rosdakarya. 